\title{
A new double-antibody sandwich ELISA targeting Plasmodium falciparum aldolase to evaluate anti-malarial drug sensitivity Lucienne Tritten ${ }^{1}$, Hugues Matile ${ }^{2}$, Reto Brun ${ }^{1}$ and Sergio Wittlin*1
}

\author{
Address: ${ }^{1}$ Swiss Tropical Institute, Socinstrasse 57, CH-4002 Basel, Switzerland and ${ }^{2}$ F. Hoffmann-La Roche Ltd., Grenzacherstrasse 124, CH-4070 \\ Basel, Switzerland \\ Email: Lucienne Tritten - lucienne.tritten@unibas.ch; Hugues Matile - hugues.matile@roche.com; Reto Brun - reto.brun@unibas.ch; \\ Sergio Wittlin* - sergio.wittlin@unibas.ch \\ * Corresponding author
}

Published: 12 October 2009

Malaria Journal 2009, 8:226 doi:10.1 I86/1475-2875-8-226
Received: 7 July 2009

Accepted: 12 October 2009

This article is available from: http://www.malariajournal.com/content/8/I/226

(C) 2009 Tritten et al; licensee BioMed Central Ltd.

This is an Open Access article distributed under the terms of the Creative Commons Attribution License (http://creativecommons.org/licenses/by/2.0), which permits unrestricted use, distribution, and reproduction in any medium, provided the original work is properly cited.

\begin{abstract}
Background: The standard in vitro test to assess anti-malarial activity of chemical compounds is the $\left[{ }^{3} \mathrm{H}\right]$ hypoxanthine incorporation assay. It is a radioactivity-based method to measure DNA replication of Plasmodium in red blood cells. The method is highly reproducible, however, the handling of radioactive material is costly, hazardous and requires the availability of appropriate technology and trained staff. Several other ways to evaluate in vitro anti-malarial activity do exist, all with their own assets and limitations.
\end{abstract}

Methods: The newly developed double-antibody sandwich ELISA described here is based on the properties of a non-overlapping pair of monoclonal antibodies directed against Plasmodium falciparum aldolase. This glycolytic enzyme possesses some unique nucleotide sequences compared to the human isoenzymes and has been highly conserved through evolution. Out of twenty possibilities, the most sensitive antibody pair was selected and used to quantitatively detect parasite aldolase in infected blood lysates.

Results: A total of 34 compounds with anti-malarial activity were tested side-by-side by ELISA and the $\left[{ }^{3} \mathrm{H}\right]$ hypoxanthine incorporation assay. The novel ELISA provided $\mathrm{IC}_{50} \mathrm{~s}$ closely paralleling those from the radioactivity-based assay $(R=0.99, p<0.00 \mathrm{l})$. At the investigated assay conditions $(72 \mathrm{~h}$ incubation time, parasitaemia $=0.3 \%$ ), the assay was found to be reproducible and easy to perform.

Conclusion: The newly developed ELISA presents several advantages over the comparative method, the $\left[{ }^{3} \mathrm{H}\right]$ hypoxanthine incorporation assay. The assay is highly reproducible, less hazardous (involves no radioactivity) and requires little and cheap technical equipment. Relatively unskilled personnel can conduct this user-friendly assay. All this makes it attractive to be employed in resource-poor laboratories.

\section{Background}

Several techniques exist to measure anti-malarial activity of chemical compounds. The most commonly used method, especially in well-equipped laboratories, is the $\left[{ }^{3} \mathrm{H}\right]$ hypoxanthine incorporation assay [1]. This method is highly reproducible, however, the handling of radioactive material is costly, hazardous and quite complex and, therefore, problematic for resource-poor locations. Moreover, radioactive material is not uniformly authorized worldwide, limiting its application geographically. A low- 
cost alternative is the schizont maturation assay, standardized by the World Health Organization. However, this test can only be carried out by the experienced microscopist, is very labour-intensive and prone to individual variability. A method that is simple to establish, highly reproducible, that requires little technical equipment and could be applicable to a field laboratory, is the enzyme-linked immunosorbent assay (ELISA). A few commercialized ELISA tests are already available, targeting either Plasmodium falciparum lactate dehydrogenase (pLDH) or histidine-rich protein 2 (HRP2) [2-6]. Like P. falciparum aldolase, pLDH is very much conserved between $P$. falciparum isolates [7]. It presents some unique differences to the human $\mathrm{LDH}$, and its level can be used to determine the drug susceptibility of malaria parasites [8]. The existing commercial kits testing pLDH are suitable with an initial parasitaemia of $0.005 \%$ of cultivated or natural strains [5]. HRP2 has recently been reported to show extensive protein sequence diversity (mainly insertions) in all of the analysed $75 \mathrm{P}$. falciparum isolates collected from geographically different areas [9]. Importantly, it was demonstrated that the HRP2 protein diversity had an effect on the sensitivities of the HRP2 detection antibodies. The same group also reports that the aldolase protein sequence shows no insertions by analysing 36 of the original 75 P. falciparum isolates [10]. This prompted us to develop a suitable double-antibody sandwich ELISA detecting $P$. falciparum aldolase to evaluate anti-malarial drug sensitivity. The newly developed aldolase ELISA was compared to the $\left[{ }^{3} \mathrm{H}\right]$ hypoxanthine incorporation assay, testing anti-malarial compounds such as OZ277 [11,12], artesunate (AS), chloroquine (CQ), pyrimethamine (PYR) and mefloquine (MEF).

\section{Methods \\ Parasite cultivation}

Plasmodium falciparum (NF54, Schiphol Airport, Netherlands) was cultivated in a modification of the medium previously described $[12,13]$, consisting of RPMI 1640 supplemented with $0.5 \%$ ALBUMAX $^{\circledR}$ II, 25 mM HEPES, $25 \mathrm{mM} \mathrm{NaHCO}_{3}$ (pH 7.3), $0.36 \mathrm{mM}$ hypoxanthine and $100 \mu \mathrm{g} / \mathrm{ml}$ neomycin. Human erythrocytes served as host cells. Cultures were maintained at $37^{\circ} \mathrm{C}$ in an atmosphere of $3 \% \mathrm{O}_{2}, 4 \% \mathrm{CO}_{2}$ and $93 \% \mathrm{~N}_{2}$ in humidified modular chambers. The NF54 isolate was provided by F. Hoffmann-LaRoche Ltd (Basel, Switzerland).

\section{Chemicals and materials}

OZ277 tosylate (MW: 565) was provided by J.L. Vennerstrom (Nebraska, USA), pyrimethamine (MW: 249) and mefloquine hydrochloride (MW: 415) were gifts from F. Hoffmann-LaRoche (Basel, Switzerland), artesunate (MW: 384) was donated by Guilin Pharma Corp. (Guilin Guangxi, China) and chloroquine diphosphate (MW: 516) was purchased from Sigma. Further anti-malarial compounds were obtained from the NGBS malaria pro- gramme, a consortium formed by the Novartis Institute for Tropical Diseases, the Genomics Institute of the Novartis Research Foundation, the Biomedical Primate Research Center and the Swiss Tropical Institute (compounds were provided by M. Rottmann, Swiss Tropical Institute Basel, Switzerland). All anti-malarial compounds were dissolved in dimethylsulfoxide (DMSO) at $10 \mathrm{mg} /$ $\mathrm{ml}$, except chloroquine, which was dissolved in water. The stock solutions were kept at $4{ }^{\circ} \mathrm{C}$ for a maximum of six months. Dilutions were prepared from the stock solution in hypoxanthine-free culture medium immediately before use. $\left[{ }^{3} \mathrm{H}\right]$ hypoxanthine was purchased from Amersham Bioscience (Buckinghamshire, UK).

The recombinant $P$. falciparum aldolases P41/5 (S359T) and $\mathrm{P} 41 / 7$ (K365N) were obtained from lambdaGT11 phage expression libraries constructed with genomic DNA of the K1 isolate of $P$. falciparum and were kindly provided by H. Döbeli, (F. Hoffmann-La Roche Ltd, Basel, Switzerland) $[14,15]$.

\section{Generation of hybridoma cell lines producing anti- Plasmodium falciparum aldolase antibodies}

Anti-P. falciparum aldolase antibodies were identified by immunoprecipitation with Protein A-sepharose (GE Healthcare) in the soluble fraction of an infected culture. Hybridoma strains P.41-1/2-7, P.41-2/3-7, P.41-4/1-12, P.41-8/11-8 and P.41-24/10-11 [16] were grown in Iscove's modified Dulbecco's medium (Invitrogen) supplemented with $10 \% \mathrm{v} / \mathrm{v}$ FBS (Gibco), 1\%v/v PenicillinStreptomycin (Gibco), 1\%v/v L-Glutamine (Gibco) in cell culture flasks, at $37^{\circ} \mathrm{C}, 5 \% \mathrm{CO}_{2}$. Monoclonal antibodies (mAbs) were purified from hybridoma supernatant on ProteinG following the manufacturer's instructions (AKTAprimeTM, Amersham Biosciences, using HiTrapTM Protein G (GE Healthcare)). The detection antibody was coupled to horseradish peroxidase (HRP, SIGMA) as described by Nakane and Kawaoi [17]. The capture antibody was stored at $4{ }^{\circ} \mathrm{C}$ in PBS supplemented with $0.02 \%$ $\mathrm{NaN}_{3}$. The HRP detection antibody was kept at $4^{\circ} \mathrm{C}$ in a PBS- $50 \%$ glycerol solution supplemented with $10 \mathrm{mg} / \mathrm{ml}$ BSA.

\section{In vitro growth-inhibition assay}

Plasmodium falciparum (NF54) growth was assessed by measuring the incorporation of the nucleic acid precursor $\left[{ }^{3} \mathrm{H}\right.$ ]hypoxanthine [18]. $\mathrm{IC}_{50}$ values were earlier found to be $0.91 \pm 0.12 \mathrm{ng} / \mathrm{ml}$ for OZ277, $1.6 \pm 0.1$ for artesunate, $5.1 \pm 0.8$ for chloroquine, $5.8 \pm 0.2$ for mefloquine [11] and $5.6 \pm 0.5 \mathrm{ng} / \mathrm{ml}$ for pyrimethamine [19]. Infected erythrocytes $(100 \mu \mathrm{l}$ per well with $2.5 \%$ haematocrit and $0.3 \%$ parasitaemia) were added to each drug titrated in $100 \mu \mathrm{l}$ duplicates over a 64-fold range. After $48 \mathrm{~h}$ incubation, $0.5 \mu \mathrm{Ci}$ of $\left[{ }^{3} \mathrm{H}\right]$ hypoxanthine in $50 \mu \mathrm{l}$ medium was added and plates were incubated for an additional $24 \mathrm{~h}$. Parasites were harvested onto glass-fiber filters and radio- 
activity was counted using a Betaplate liquid scintillation counter (Wallac, Zurich). The results were recorded as counts per minute (cpm) per well at each drug concentration and expressed as a percentage of the untreated controls.

\section{Double antibody sandwich ELISA}

96-well microtiter plates (Maxisorp, Nunc) were coated with $100 \mu \mathrm{l} /$ well of the capture antibody P.41-24/10-11 ( $5 \mu \mathrm{g} / \mathrm{ml}$ in PBS) overnight at $4{ }^{\circ} \mathrm{C}$. The plates were then saturated with $200 \mu \mathrm{l} /$ well of $1 \%$ BSA in PBS-Tween 20 $(0.05 \%)$ for 1 hour at $37^{\circ} \mathrm{C} .50 \mu \mathrm{l}$ of the test samples were then added and incubated $1 \mathrm{~h}$ at $37^{\circ} \mathrm{C}$. Then, $50 \mu \mathrm{l} /$ well of the detection antibody P.41-2/3-7 - HRP $(0.8 \mu \mathrm{g} / \mathrm{ml})$ were added, and the plates incubated $1 \mathrm{~h}$ in the dark at room temperature. Finally, $100 \mu \mathrm{l} /$ well of the substrate (Tetramethylbenzidine) solution was added and the reac- tion stopped after 5 min with $100 \mu \mathrm{l} 1 \mathrm{~N} \mathrm{H}_{2} \mathrm{SO}_{4}$. The optical densities (ODs) were measured at $450 \mathrm{~nm}$ by an ELISA plate reader (Biotrak visible plate reader, Amersham Pharmacia Biotech). Between each incubation step, the plates were washed four times with PBS-Tween (0.05\% Tween20).

\section{Statistics}

Fifty percent inhibitory concentrations $\left(\mathrm{IC}_{50} \mathrm{~s}\right)$ were determined in XLfit from IDBS by a 4 parameter logistic model. After controlling the normal distribution of the data, a correlation coefficient between the results obtained sideby-side by the two methods was determined by a standard Pearson's correlation analysis (Stata 9.1) and a Bland-Altman plot was performed, testing the agreement between them (Stata 9.1).

Table I: $I_{50}$ s for OZ277, AS, CQ, PYR and MEF obtained from the aldolase ELISA and the $\left[{ }^{3} \mathrm{H}\right]$ hypoxanthine method with the $P$. falciparum strain NF54

\section{Anti-malarial compound Drug assay $(n=3)$ IC $50 \pm$ SD $(\mathrm{ng} / \mathrm{ml}) \quad\left[{ }^{3} \mathrm{H}\right]$ hypoxanthine data $(\mathrm{ng} / \mathrm{ml})$ from Vennerstrom et al, 2004; Maerki et al, 2006}

\begin{tabular}{llll}
\hline OZ277 & {$\left[{ }^{3} \mathrm{H}\right]$ hypoxanthine } & $0.36( \pm 0.03)$ & $0.91( \pm 0.12)$ \\
\hline OZ277 & Aldolase ELISA & $0.63( \pm 0.18)$ \\
\hline
\end{tabular}

\begin{tabular}{llll}
\hline AS & {$\left[{ }^{3} \mathrm{H}\right]$ hypoxanthine } & $0.91( \pm 0.32)$ & $1.6( \pm 0.1)$ \\
\hline AS & Aldolase ELISA & $1.6( \pm 0.3)$ \\
\hline
\end{tabular}

\begin{tabular}{llll}
\hline $\mathrm{CQ}$ & {$\left[{ }^{3} \mathrm{H}\right]$ hypoxanthine } & $3.8( \pm 0.5)$ & $5.1( \pm 0.8)$ \\
\hline $\mathrm{CQ}$ & Aldolase ELISA & $5.3( \pm 0.7)$ \\
\hline
\end{tabular}

\begin{tabular}{|c|c|c|c|}
\hline PYR & {$\left[{ }^{3} \mathrm{H}\right]$ hypoxanthine } & $3.8( \pm 0.6)$ & $5.6( \pm 0.5)$ \\
\hline PYR & Aldolase ELISA & $7.9( \pm 2.1)$ & \\
\hline
\end{tabular}

\begin{tabular}{llll}
\hline MEF & {$\left[{ }^{3} \mathrm{H}\right]$ hypoxanthine } & $4.3( \pm \mathrm{I} .0)$ & $5.8( \pm 0.2)$ \\
\hline MEF & Aldolase ELISA & $6.9( \pm 0.5)$
\end{tabular}

Geometric mean $\mathrm{IC}_{50} \mathrm{~s}$ with $95 \% \mathrm{Cls}$ for OZ277, artesunate (AS), chloroquine (CQ), pyrimethamine (PYR) and mefloquine (MEF) determined sideby-side by $\left[{ }^{3} \mathrm{H}\right]$ hypoxanthine assay and aldolase ELISA. Previously published $\mathrm{IC}_{50} \mathrm{~s}$ for $\left[{ }^{3} \mathrm{H}\right]$ hypoxanthine assay are given for comparison. Mean values shown from $\mathrm{n}=3$ independent experiments. 


\section{Results}

Five anti-recombinant aldolase monoclonal antibodies were tested both as capture as well as detection antibodies (HRP-labeled) in a double-antibody sandwich ELISA targeting $P$. falciparum recombinant aldolase P41/7 (highest concentration was $10 \mu \mathrm{g} / \mathrm{ml}$ ). Ultimately, the antibody pair P.41-24/10-11; P.41-2/3-7+HRP was selected, showing a good specificity (steep curve) and the broadest dynamic range (OD span). When $P$. falciparum cultures (NF54) of e.g. initial parasitaemias of $0.3 \%$ or $0.03 \%$ were incubated for 72 hours and then lysed and analysed by ELISA, the observed ODs were 2.3 and 0.23 , with a background signal (uninfected blood sample) of about 0.04 . Having obtained such a solid signal to background ratio of $>50$ at the higher starting parasitaemia $(0.3 \%)$, and since $0.3 \%$ is the typical parasitaemia employed for the hypoxanthine assay, an ELISA with five anti-malarial compounds was performed under these conditions, side-byside with a $\left[{ }^{3} \mathrm{H}\right]$ hypoxanthine incorporation assay. After $48 \mathrm{~h},\left[{ }^{3} \mathrm{H}\right]$ hypoxanthine dissolved in assay medium was added to the hypoxanthine incorporation assay, whereas the ELISA received the same volume of hypoxanthine-free assay medium. The geometric mean $\mathrm{IC}_{50} \mathrm{~s} \pm \mathrm{SDs}$ obtained from the two methods are shown in Table 1, together with the expected $\left[{ }^{3} \mathrm{H}\right]$ hypoxanthine assay values.

An excellent correlation coefficient of $\mathrm{R}=0.991(\mathrm{P}<$ 0.001 ) was found when additional 29 anti-malarial compounds were tested and both $\log \mathrm{IC}_{50} \mathrm{~s}$ of all compounds, including OZ277, AS, CQ, PY and MEF, plotted (Figure $1)$.

To test the agreement between ELISA and $\left[{ }^{3} \mathrm{H}\right]$ hypoxanthine incorporation assay, the difference in $\log \mathrm{IC}_{50} \mathrm{~s}$ obtained from the two methods were plotted against their mean value in a Bland-Altman plot (Figure 2). The two methods were found to agree, as $>96 \%$ of the values lie in acceptable broad limits of agreement (-0.85 to 0.32$)$.

\section{Discussion}

The novel ELISA provides $\mathrm{IC}_{50}$ s closely paralleling those from the standard $\left[{ }^{3} \mathrm{H}\right]$ hypoxanthine incorporation assay (Table 1), with P.41-24/10-11 as capture antibody and P.41-2/3-7-HRP as detection antibody targeting P. falciparum aldolase. The excellent correlation between $\mathrm{IC}_{50} \mathrm{~S}$ determined by the $\left[{ }^{3} \mathrm{H}\right]$ hypoxanthine incorporation assay and by aldolase ELISA $(\mathrm{R}=0.991, \mathrm{P}<0.001$; Figure 1$)$ was further confirmed by the Bland-Altman plot (Figure 2), showing a general trend of the two methods to agree nicely. The limits of agreement correlate with the findings of Noedl et al who compared the $\left[{ }^{3} \mathrm{H}\right]$ hypoxanthine incorporation assay and the HRP2 ELISA [20]. Interestingly, the aldolase ELISA tends in all cases to measure slightly higher $\mathrm{IC}_{50} \mathrm{~s}$ than the $\left[{ }^{3} \mathrm{H}\right]$ hypoxanthine incorporation assay. However, this observation should have no impact on the power of the assay.

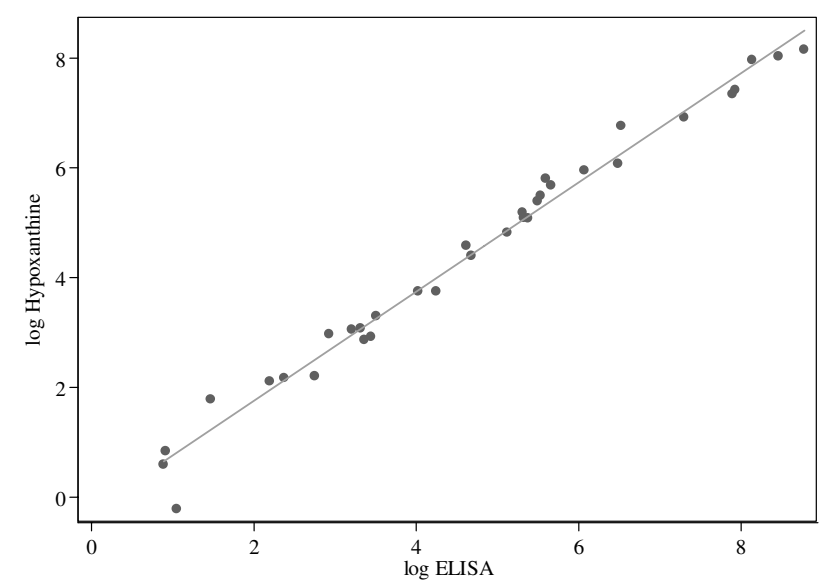

Figure I

Correlation of $\log I \mathrm{I}_{50}$ s obtained from the aldolase ELISA and the $\left[{ }^{3} \mathrm{H}\right]$ hypoxanthine method with the $P$. falciparum strain NF54. 34 compounds were tested by ELISA and $\left[{ }^{3} \mathrm{H}\right]$ hypoxanthine incorporation $(n=1)$ with the $P$. falciparum strain NF54. The $\log I_{50}$ in $\mathrm{nM}$ (or $\mathrm{ng} / \mathrm{ml}$ for the standard compounds) from $\left[{ }^{3} \mathrm{H}\right]$ hypoxanthine incorporation is plotted against the log $I C_{50}$ from ELISA, for each compound. $(n=34$, correlation coefficient $(R)=0.991$ and $p$ value $<0.00 \mathrm{I})$.

Aldolase is commonly used as a pan-malaria antigen in rapid diagnostic tests (RDTs) [21]. It can, therefore, not be ruled out that our monoclonal antibodies could crossreact with aldolase from other Plasmodium species. This should be kept in mind when embarking in future drug susceptibility testing efforts in species-overlapping zones.

Aldolase- and pLDH-based RDTs are reported to be less sensitive than HRP2-based tests, due to the transient presence in blood of the first $[21,22]$. However, since the lowest parasitaemia tested in this study $(0.03 \%)$ did result in a solid signal to background ratio of $\sim 5$, the sensitivity is not expected to be an issue for drug sensitivity testing in the field. Furthermore, the aldolase amino acid sequence is highly conserved, preventing detection failures, as seen in the case of HRP2 [9]. The aldolase ELISA presents no drawbacks or assets over pLDH-based assays.

\section{Conclusion}

The novel aldolase ELISA assay is highly reproducible, less hazardous than the $\left[{ }^{3} \mathrm{H}\right]$ hypoxanthine incorporation assay and requires little and cheap technical equipment. Relatively unskilled personnel can conduct this userfriendly assay. All this makes it attractive to be employed in resource-poor laboratories.

The fact that the $P$. falciparum aldolase has been highly conserved during evolution [10] renders aldolase an antibody target of choice for the analysis of field isolates. It 


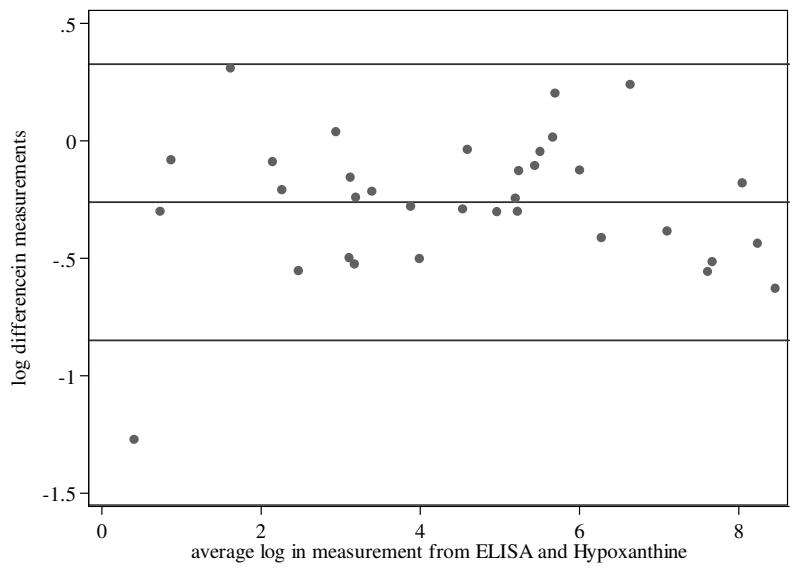

Figure 2

Difference in $\log I C_{50}$ s obtained from the the aldolase ELISA and the $\left[{ }^{3} \mathrm{H}\right]$ hypoxanthine method. Bland-Altman plot of the difference in $\log \mathrm{IC}_{50} \mathrm{~s}$ in $\mathrm{nM}$ (or $\mathrm{ng} / \mathrm{ml}$ for the standard compounds) for 34 anti-malarial compounds, determined by ELISA and $\left[{ }^{3} \mathrm{H}\right]$ hypoxanthine assay plotted against their mean. The mean difference is -0.261 . The limits of agreement are represented by \pm 2 SD (-0.85 to 0.32$)$.

also provides a considerable advantage over the HRP2 ELISA, since the HRP2 gene sequence is showing an extensive diversity, altering the sensitivity of some commercial diagnostic tests.

However, before proceeding to drug susceptibility testing in endemic countries, further investigations with more parasite isolates should be performed in order to determine the lowest measurable parasitaemia (sensitivity) of the aldolase ELISA as well as if the here described monoclonal antibodies cross-react with aldolase from other Plasmodium species.

\section{Competing interests}

The authors declare that they have no competing interests.

\section{Authors' contributions}

LT was the student in charge of developing the aldolase ELISA and did most of the laboratory work. HM, SW and RB supervised the project, directed the research and were involved in writing the manuscript. All authors have read and approved the final manuscript.

\section{Acknowledgements}

We would like to acknowledge Christian Scheurer, Sonja Keller-Maerki, Doris Zulauf and Bernard Rutten for their constant support through discussions and technical assistance.

\section{References}

I. Fidock DA, Rosenthal PJ, Croft SL, Brun R, Nwaka S: Antimalarial drug discovery: efficacy models for compound screening. Nat Rev Drug Discov 2004, 3:509-520.

2. Noed $\mathrm{H}$, Wongsrichanalai C, Wernsdorfer WH: Malaria drug-sensitivity testing: new assays, new perspectives. Trends Parasitol 2003, I9:175-181.

3. Brockman A, Singlam S, Phiaphun L, Looareesuwan S, White NJ, Nosten F: Field evaluation of a novel colorimetric method--double-site enzyme-linked lactate dehydrogenase immunodetection assay--to determine drug susceptibilities of Plasmodium falciparum clinical isolates from northwestern Thailand. Antimicrob Agents Chemother 2004, 48: I426-I 429.

4. Druilhe P, Moreno A, Blanc C, Brasseur PH, Jacquier P: A colorimetric in vitro drug sensitivity assay for Plasmodium falciparum based on a highly sensitive double-site lactate dehydrogenase antigen-capture enzyme-linked immunosorbent assay. Am J Trop Med Hyg 200I, 64:233-24I.

5. Kaddouri H, Nakache S, Houze S, Mentre F, Le Bras J: Assessment of the drug susceptibility of Plasmodium falciparum clinical isolates from Africa by using a Plasmodium lactate dehydrogenase immunodetection assay and an inhibitory maximum effect model for precise measurement of the 50-percent inhibitory concentration. Antimicrob Agents Chemother 2006, 50:3343-3349.

6. Noedl H, Attlmayr B, Wernsdorfer WH, Kollaritsch H, Miller RS: A histidine-rich protein 2-based malaria drug sensitivity assay for field use. Am J Trop Med Hyg 2004, 7 I:7II-7I4.

7. Talman AM, Duval L, Legrand E, Hubert V, Yen S, Bell D, Le Bras J, Ariey F, Houze S: Evaluation of the intra- and inter-specific genetic variability of Plasmodium lactate dehydrogenase. Malar J 2007, 6: I40.

8. Basco LK, Marquet F, Makler MM, Le Bras J: Plasmodium falciparum and Plasmodium vivax: lactate dehydrogenase activity and its application for in vitro drug susceptibility assay. Exp Parasitol I995, 80:260-27I.

9. Baker J, McCarthy J, Gatton M, Kyle DE, Belizario V, Luchavez J, Bell $D$, Cheng Q: Genetic diversity of Plasmodium falciparum histidine-rich protein 2 (PfHRP2) and its effect on the performance of PfHRP2-based rapid diagnostic tests. J Infect Dis 2005, 1 92:870-877.

10. Lee N, Baker J, Bell D, McCarthy J, Cheng Q: Assessing the genetic diversity of the aldolase genes of Plasmodium falciparum and Plasmodium vivax and its potential effect on performance of aldolase-detecting rapid diagnostic tests. J Clin Microbiol 2006, 44:4547-4549.

I I. Vennerstrom JL, Arbe-Barnes S, Brun R, Charman SA, Chiu FC, Chollet J, Dong Y, Dorn A, Hunziker D, Matile H, et al:: Identification of an antimalarial synthetic trioxolane drug development candidate. Nature 2004, 430:900-904.

12. Snyder C, Chollet J, Santo-Tomas J, Scheurer C, Wittlin S: In vitro and in vivo interaction of synthetic peroxide $R B x I I I 60$ (OZ277) with piperaquine in Plasmodium models. Exp Parasitol 2007, I I 5:296-300.

13. Trager $W$, Jensen JB: Human malaria parasites in continuous culture. Science 1976, 193:673-675.

14. Dobeli H, Trzeciak A, Gillessen D, Matile H, Srivastava IK, Perrin LH, Jakob PE, Certa U: Expression, purification, biochemical characterization and inhibition of recombinant Plasmodium falciparum aldolase. Mol Biochem Parasitol 1990, 41:259-268.

I5. Certa U, Ghersa P, Dobeli H, Matile H, Kocher HP, Shrivastava IK, Shaw AR, Perrin LH: Aldolase activity of a Plasmodium falciparum protein with protective properties. Science 1988, 240:1036-1038.

16. Daubenberger CA, Tisdale EJ, Curcic M, Diaz D, Silvie O, Mazier D, Eling W, Bohrmann B, Matile H, Pluschke G: The N'-terminal domain of glyceraldehyde-3-phosphate dehydrogenase of the apicomplexan Plasmodium falciparum mediates GTPase Rab2-dependent recruitment to membranes. Biol Chem 2003, 384: I227-I 237.

17. Nakane PK, Kawaoi A: Peroxidase-labeled antibody. A new method of conjugation. J Histochem Cytochem 1974, 22:1084-1091. 
18. Desjardins RE, Canfield CJ, Haynes JD, Chulay JD: Quantitative assessment of antimalarial activity in vitro by a semiautomated microdilution technique. Antimicrob Agents Chemother 1979, 16:710-7|8.

19. Maerki S, Brun R, Charman SA, Dorn A, Matile H, Wittlin S: In vitro assessment of the pharmacodynamic properties and the partitioning of OZ277/RBX-I I I60 in cultures of Plasmodium falciparum. J Antimicrob Chemother 2006, 58:52-58.

20. Noedl H, Wernsdorfer WH, Miller RS, Wongsrichanalai C: Histidine-rich protein II: a novel approach to malaria drug sensitivity testing. Antimicrob Agents Chemother 2002, 46: I658-I 664.

21. Murray CK, Bennett JW: Rapid diagnosis of malaria. Interdiscip Perspect Infect Dis 2009, 2009:4I5953.

22. Bell DR, Wilson DW, Martin LB: False-positive results of a Plasmodium falciparum histidine-rich protein 2-detecting malaria rapid diagnostic test due to high sensitivity in a community with fluctuating low parasite density. Am J Trop Med Hyg 2005, 73:199-203.

Publish with Bio Med Central and every scientist can read your work free of charge

"BioMed Central will be the most significant development for disseminating the results of biomedical research in our lifetime. "

Sir Paul Nurse, Cancer Research UK

Your research papers will be:

- available free of charge to the entire biomedical community

- peer reviewed and published immediately upon acceptance

- cited in PubMed and archived on PubMed Central

- yours - you keep the copyright

Submit your manuscript here:

http://www.biomedcentral.com/info/publishing_adv.asp 